\title{
Zmiany w koniunkturze gospodarczej Polski w wyniku epidemii COVID-19
}

Changes in the economic situation in Poland as a result of the COVID-19 epidemic

\section{Wprowadzenie}

Skrótem COVID-19 (Coronavirus Disease 2019) oznaczono ostrą chorobę zakaźną układu oddechowego, wywołaną zakażeniem wirusem SARS-CoV-2. Została ona po raz pierwszy rozpoznana i opisana w grudniu $2019 \mathrm{r}$. w środkowych Chinach, w mieście Wuhan, w prowincji Hubei (Chen i in., 2020; Huang i in., 2020; Lu, Stratton i Tang, 2020a, 2020b). Nastąpiło wiele zachorowań, które rozprzestrzeniły się poza granicę Chin, praktycznie do wszystkich krajów świata. Światowa Organizacja Zdrowia (World Health Organization - WHO) 11 marca 2020 r. uznała serię zachorowań na COVID-19 występującą od grudnia 2019 r. za pandemię. Wówczas było ponad 118 tys. potwierdzonych przypadków zakażenia w 114 krajach, a życie straciło 4291 osób (World Health Organization [WHO], 2020a). Tempo i przebieg pandemii były zróżnicowane. Do 10 lipca 2020 r. potwierdzono 12,1 mln przypadków zakażenia na świecie, a życie straciło 550 tys. ludzi. Na Europę przypadało 2,85 mln zakażeń i 202 tys. śmiertelnych przypadków (WHO, 2020b). W Polsce do 10 lipca odnotowano 37216 zakażeń, w tym 1562 zgonów (Serwis Rzeczypospolitej Polskiej, 2020). Nieprzerwane rozprzestrzenianie się choroby wynikało z braku szczepionki i skutecznych środków terapeutycznych przeciwko temu nowemu wirusowi (Jayadev i Shetty, 2020; Shetty, Ghosh, Honavar, Khamar i Sethu, 2020).

W wielu państwach wprowadzono ograniczenia przemieszczania, a pewne działalności zostały urzędowo zakazane. Pandemia miała więc duży wpływ na życie społeczne i gospodarkę. Scenariusze radzenia sobie z epidemią były różne 
w poszczególnych krajach (Jarynowski, Wójta-Kempa, Płatek i Czopek, 2020). W Polsce ograniczenia dotyczyły większości branż i zostały wprowadzone od 13 marca 2020 r. Od 20 marca zaczął w Polsce obowiązywać stan epidemii (Rozporządzenie Ministra Zdrowia z dnia 13 marca 2020 r. w sprawie ogłoszenia na obszarze Rzeczypospolitej Polskiej stanu zagrożenia epidemicznego, 2020; Rozporządzenie Ministra Zdrowia z dnia 20 marca 2020 r. w sprawie ogłoszenia na obszarze Rzeczypospolitej Polskiej stanu epidemii, 2020). Wszystkie ograniczenia poważnie wpłynęły na koniunkturę gospodarczą w Polsce.

Koniunktura gospodarcza oznacza wszelkie zmiany aktywności gospodarczej przejawiające się w zmianach podstawowych wskaźników ekonomicznych. Ukazuje ona cykliczny przebieg procesu gospodarowania i dotyczy zarówno stanu, jak i dynamiki zjawisk oraz procesów gospodarczych. Miernikami koniunktury gospodarczej najczęściej są tempo wzrostu PKB, PKB per capita, poziom i tempo wzrostu inwestycji, relacja inwestycji do PKB, stopa bezrobocia. Oczywiście stosowanie poszczególnych mierników jest obciążone różnymi wadami. Wskaźniki makroekonomiczne prezentowane są najczęściej kwartalnie lub miesięcznie w odniesieniu do analogicznego okresu roku poprzedniego lub bezpośrednio poprzedzającego. Stosuje się różne rodzaje wskaźników i barometrów koniunktury gospodarczej. Często są one syntetyczne i zawierają w sobie kilka mierników dotyczących danego działu gospodarczego. Nadaje się im wagi (Adamowicz i Walczyk, 2017; Gierańczyk, 2014; Poberezhets, 2015).

\section{Cele i metodyka badań}

Celem badań było rozpoznanie sytuacji i przedstawienie zmian w koniunkturze gospodarczej Polski w wyniku epidemii COVID-19. Celami szczegółowymi były: określenie stopnia zmian koniunktury gospodarczej w poszczególnych sektorach i działalnościach, ukazanie wielkości zmian w 2020 r. w porównaniu z kryzysowymi latami 2008-2009, ustalenie związku liczby zakażeń ze zmianą koniunktury w podstawowych rodzajach działalności. W pracy postawiono hipotezę, według której największe pogorszenie koniunktury gospodarczej w $2020 \mathrm{r}$. dotyczyło podobnych branż jak w latach 2008-2009. Kryzysy gospodarcze w podanych okresach były wywołane innymi przyczynami, ale według założeń autora konsekwencje kryzysów mogły być podobne, tzn. dotyczyć podobnych branż. W sposób celowy wybrano do badań terytorium Polski. Kraj ten dosyć łagodnie odczuł konsekwencje kryzysu gospodarczego z lat 2008-2009, co może sugerować, że gospodarka Polski była w dobrym stanie, w pewnym sensie odporna 
na jego poważne konsekwencje. Postanowiono sprawdzić, czy podobnie było w przypadku kryzysu z 2020 r. Okres badawczy dotyczył lat 2008-2009 i 2020 (od stycznia do czerwca). Źródła materiałów stanowiła literatura przedmiotu, dane GUS. Do analizy i prezentacji materiałów zastosowano metody opisową, tabelaryczną, graficzną, średnie arytmetyczne, wskaźnik syntetyczny koniunktury gospodarczej, współczynnik koncentracji Giniego, analizę koncentracji za pomocą krzywej Lorenza, współczynnik korelacji liniowej Pearsona.

Ogólny wskaźnik syntetyczny koniunktury gospodarczej GUS dla poszczególnych rodzajów działalności bazuje na zestandaryzowanych wskaźnikach prostych wyrównanych sezonowo, pochodzących z badań koniunktury gospodarczej:

- przetwórstwa przemysłowego - wykorzystuje się wskaźniki bieżącego poziomu zapasów (z odwrotnym znakiem), bieżącego portfela zamówień (stanu) oraz przewidywanej produkcji;

- budownictwa - mają zastosowanie wskaźniki bieżącego portfela zamówień (stanu) i przewidywanego zatrudnienia;

- handlu detalicznego - wykorzystuje się wskaźniki bieżącego poziomu zapasów (z odwrotnym znakiem), sprzedaży w ostatnich trzech miesiącach oraz przewidywanej sprzedaży;

- $\quad$ usług - mają zastosowanie wskaźniki ogólnej sytuacji jednostki, popytu w ostatnich trzech miesiącach oraz przewidywanego popytu.

Na ogólny wskaźnik syntetyczny koniunktury gospodarczej składają się podane wskaźniki proste z przyporządkowanymi im wagami: dla przetwórstwa przemysłowego (50\%), usług (38\%), handlu detalicznego (6\%), budownictwa (6\%). Ogólny wskaźnik syntetyczny koniunktury gospodarczej jest zestandaryzowany wobec poziomu 100 o odchyleniu standardowym 10. Gdy jego wartość jest większa od 100, oznacza to, że wskaźnik kształtuje się na poziomie powyżej średniej długookresowej, a gdy jest niższa od 100, to poniżej tej średniej. W przypadku przetwórstwa przemysłowego badaniem są objęte podmioty zatrudniające minimum 10 pracowników. W pozostałych sektorach (budownictwo, handel, usługi) uczestniczą wszystkie podmioty.

\section{Wyniki badań i dyskusja}

Koniunktura gospodarcza w Polsce podlegała zmianom. Bardzo dobrym okresem były lata 2004-2008 (rys. 1). W okresie kryzysu gospodarczego zauważalnego w Polsce od końca 2008 r. nastąpiło pogorszenie się koniunktury gospodarczej na skutek globalnego kryzysu finansowego. Kolejny gorszy okres był w 2013 r., po 
czym nastąpiła stabilizacja. Szczególnie korzystne były natomiast lata 2017-2019. W marcu 2020 r. nastąpiło załamanie się koniunktury spowodowane epidemią COVID-19. W przypadku jej wskaźników odnoszących się do poszczególnych sektorów gospodarki prawidłowości były podobne, różnice występowały jedynie w natężeniu i skali tych zmian.

Rysunek 1. Wskaźnik syntetyczny koniunktury gospodarczej w Polsce od stycznia 2004 r. do czerwca 2020 r.

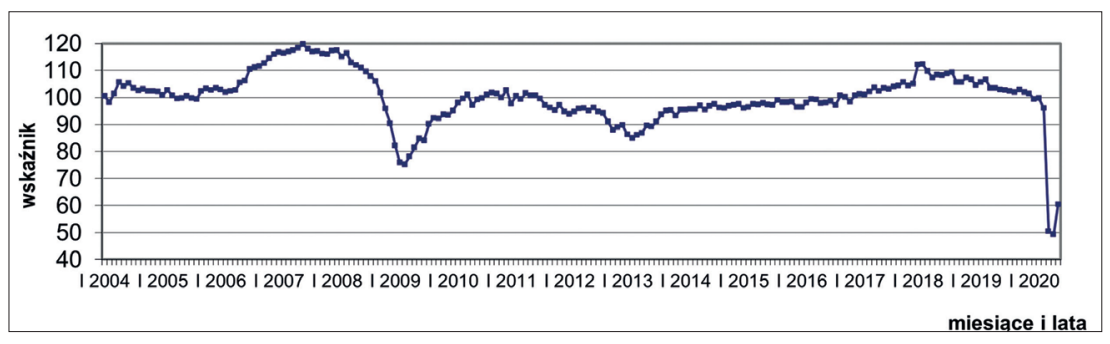

Źródło: opracowanie własne na podstawie GUS.

Dwa największe kryzysy gospodarcze w ostatnich kilkunastu latach miały inne przyczyny, co również mogło wpłynąć na siłę reakcji i zmiany koniunktury w poszczególnych sektorach gospodarki. Na podstawie przeprowadzonej analizy danych określono okresy, w których nastąpiła zła koniunktura gospodarcza. W przypadku kryzysu gospodarczego w latach 2008-2009 jej pogorszenie nastąpiło od listopada 2008 r., poprawę zaś odnotowano dopiero od kwietnia $2010 \mathrm{r}$. (tabela 1). W przypadku kryzysu gospodarczego w 2020 r. można zauważyć gorszą koniunkturę jeszcze przed wybuchem epidemii. Marzec 2020 r. charakteryzował się niewielkim jej pogorszeniem, a drastyczne spadki wystąpiły w kwietniu i maju. W czerwcu widoczne było nieznaczne polepszenie koniunktury.

Tabela 1. Wskaźnik syntetyczny koniunktury gospodarczej w najważniejszych działach gospodarki w czasach kryzysów gospodarczych w Polsce

\begin{tabular}{|l|c|c|c|c|c|}
\hline \multirow{2}{*}{$\begin{array}{c}\text { Miesiące } \\
\text { i lata }\end{array}$} & \multicolumn{5}{|c|}{ Wskaźnik koniunktury w działach gospodarki } \\
\cline { 2 - 6 } & Ogółem & Przemysł & Budownictwo & Handel detaliczny & Usługi \\
\hline X 2008 & 101,7 & 95,7 & 109,7 & 101,3 & 108,5 \\
\hline XI 2008 & 95,8 & 88,6 & 107,7 & 99,4 & 102,9 \\
\hline XII 2008 & 90,3 & 81,8 & 104,8 & 93,4 & 98,7 \\
\hline I 2009 & 82,2 & 72,0 & 94,2 & 93,4 & 92,0 \\
\hline II 2009 & 76,0 & 68,7 & 86,4 & 82,6 & 82,9 \\
\hline III 2009 & 75,2 & 69,9 & 81,5 & 77,8 & 80,8 \\
\hline
\end{tabular}




\begin{tabular}{|l|c|c|c|c|c|}
\hline \multirow{2}{*}{$\begin{array}{c}\text { Miesiące } \\
\text { i lata }\end{array}$} & \multicolumn{5}{|c|}{ Wskaźnik koniunktury w działach gospodarki } \\
\cline { 2 - 6 } & Ogółem & Przemysł & Budownictwo & Handel detaliczny & Usługi \\
\hline IV 2009 & 78,2 & 71,6 & 82,6 & 88,7 & 84,5 \\
\hline V 2009 & 81,4 & 74,7 & 83,6 & 93,9 & 87,8 \\
\hline VI 2009 & 84,8 & 79,3 & 83,6 & 91,4 & 91,2 \\
\hline VII 2009 & 84,1 & 77,4 & 83,8 & 93,1 & 91,6 \\
\hline VIII 2009 & 90,1 & 85,6 & 85,6 & 98,0 & 95,6 \\
\hline IX 2009 & 92,4 & 89,1 & 86,4 & 95,9 & 97,3 \\
\hline X 2009 & 92,2 & 88,7 & 86,9 & 92,3 & 97,7 \\
\hline XI 2009 & 93,7 & 90,4 & 87,4 & 91,4 & 99,7 \\
\hline XII 2009 & 93,5 & 89,2 & 90,4 & 91,2 & 100,2 \\
\hline I 2010 & 95,2 & 90,4 & 90,4 & 89,8 & 103,4 \\
\hline II 2010 & 98,1 & 92,7 & 89,7 & 94,3 & 107,3 \\
\hline III 2010 & 99,5 & 95,4 & 92,3 & 96,6 & 106,7 \\
\hline IV 2010 & 101,1 & 94,5 & 94,3 & 97,4 & 111,6 \\
\hline \multicolumn{7}{|c|}{ Kryzys gospodarczy w wyniku COVID-19 } & \\
\hline I 2020 & 99,3 & 101,4 & 112,2 & 100,7 & 94,2 \\
\hline II 2020 & 99,7 & 102,7 & 111,7 & 101,7 & 93,3 \\
\hline III 2020 & 96,0 & 99,7 & 110,4 & 100,9 & 88,0 \\
\hline IV 2020 & 50,4 & 64,2 & 76,9 & 45,0 & 28,5 \\
\hline V 2020 & 49,3 & 65,3 & 82,6 & 43,9 & 23,2 \\
\hline VI 2020 & 60,5 & 73,2 & 88,5 & 59,4 & 39,0 \\
\hline
\end{tabular}

Źródło: opracowanie własne na podstawie GUS.

Okresy dwóch kryzysów gospodarczych zestawiono, aby porównać skalę pogorszenia się koniunktury gospodarczej oraz sytuację w poszczególnych sektorach w tym zakresie. W czasie kryzysu gospodarczego z lat 2008-2009 jej pogorszenie nie było drastyczne, bo najniższy wskaźnik wyniósł 75,2 w marcu 2009 r. W czasie epidemii COVID-19 w maju wskaźnik koniunktury sięgnął zaledwie 49,3. Różnice występowały też w poszczególnych sektorach. W latach 2008-2009 kryzys gospodarczy wpłynął najbardziej na przetwórstwo przemysłowe, następnie na budownictwo, najmniej zaś na handel detaliczny i i usługi. W 2020 r. największe pogorszenie się koniunktury gospodarczej wystąpiło zdecydowanie w sektorze usług (średni wskaźnik za miesiące marzec-czerwiec 2020 wyniósł 44,7), dalej w handlu detalicznym $(62,3$ i 64,1), przemyśle $(75,6)$, najmniejsze zaś w budownictwie $(89,6)$. 
W kolejnym etapie określono miesiące, w których następowało pogorszenie się koniunktury gospodarczej dla większości działalności. Dla lat 2008-2009 taka sytuacja występowała od grudnia 2008 r. do lipca 2009 r. (łącznie 8 miesięcy). Dla 2020 r. takie spadki odnotowano w trzech miesiącach, tj. kwietniu, maju i czerwcu. Dla każdego z tych okresów policzono średnią miesięczną wskaźnika koniunktury gospodarczej. Gałęzie przetwórstwa przemysłowego zostały uporządkowane w kolejności rosnącej według wyniku dotyczącego 2020 r. W 2020 r. największe pogorszenie koniunktury gospodarczej nastąpiło w przypadku produkcji skór, odzieży, samochodów i mebli (tabela 2). Były to produkty wymagające osobistej obecności podczas zakupu. W przypadku ograniczonego popytu ze strony konsumentów redukcji podlegała produkcja tego rodzaju wyrobów. Z kolei wzrost koniunktury gospodarczej zaobserwowano przy wytwarzaniu wyrobów chemicznych i leków. Były to produkty, na które wzrósł popyt w czasie epidemii. Stwierdzono również, że im większe było przedsiębiorstwo, tym mniej odczuwało pogorszenie się koniunktury. Najgorsza sytuacja była w obszarze związanym z produkcją energii, dóbr inwestycyjnych i trwałych dóbr konsumpcyjnych. Najmniejsze spadki koniunktury odnotowano w branży żywności i napoi oraz nietrwałych dóbr konsumpcyjnych. W trakcie epidemii ludzie musieli zaspokajać swoje podstawowe potrzeby fizjologiczne związane $z$ jedzeniem. Zrezygnowali natomiast $\mathrm{z}$ dóbr wyższego rzędu - inwestycji - po części na skutek zawieszenia wielu działalności i zakazu wychodzenia z domu. W latach 2008-2009 skala pogorszenia koniunktury była mniejsza. W 2009 r. duży jej spadek nastąpił w przypadku produkcji metali, wyrobów tekstylnych i odzieży. Z kolei bardzo dobrze funkcjonowała produkcja leków, artykułów spożywczych, papieru i chemikaliów. Występowały więc różnice między oboma kryzysami, a główną ich przyczyną były administracyjne ograniczenia działalności, które wykluczały popyt na dane produkty. W obu kryzysach najbardziej ich skutki odczuwały najmniejsze przedsiębiorstwa. Podobne były też obszary działalności pod względem wrażliwości na kryzys gospodarczy.

Tabela 2. Wskaźnik syntetyczny koniunktury gospodarczej w działalnościach przetwórstwa przemysłowego w Polsce

\begin{tabular}{|l|c|c|}
\hline \multirow{2}{*}{ Gałęzie przetwórstwa przemysłowego } & \multicolumn{2}{|c|}{$\begin{array}{c}\text { Średnie wskaźniki koniunktury } \\
\text { w latach }\end{array}$} \\
\cline { 2 - 3 } & $2008-2009$ & 2020 \\
\hline Produkcja skór i wyrobów ze skór wyprawionych & $-18,6$ & $-53,4$ \\
\hline Produkcja odzieży & $-32,5$ & $-46,0$ \\
\hline
\end{tabular}




\begin{tabular}{|c|c|c|}
\hline \multirow[t]{2}{*}{ Gałęzie przetwórstwa przemysłowego } & \multicolumn{2}{|c|}{$\begin{array}{l}\text { Średnie wskaźniki koniunktury } \\
\text { w latach }\end{array}$} \\
\hline & 2008-2009 & 2020 \\
\hline $\begin{array}{l}\text { Produkcja pojazdów samochodowych, przyczep i naczep, } \\
\text { z wyłączeniem motocykli }\end{array}$ & $-18,6$ & $-45,2$ \\
\hline Produkcja mebli & $-1,4$ & $-40,3$ \\
\hline $\begin{array}{l}\text { Wytwarzanie i przetwarzanie koksu i produktów rafinacji } \\
\text { ropy naftowej }\end{array}$ & $-23,6$ & $-32,2$ \\
\hline $\begin{array}{l}\text { Produkcja wyrobów z drewna oraz korka, z wyłączeniem } \\
\text { mebli; produkcja wyrobów ze słomy i materiałów używa- } \\
\text { nych do wyplatania }\end{array}$ & $-21,8$ & $-28,3$ \\
\hline Produkcja wyrobów tekstylnych & $-34,7$ & $-27,5$ \\
\hline $\begin{array}{l}\text { Produkcja metalowych wyrobów gotowych, z wyłącze- } \\
\text { niem maszyn i urządzeń }\end{array}$ & $-20,4$ & $-26,1$ \\
\hline Poligrafia i reprodukcja zapisanych nośników informacji & $-12,8$ & $-21,2$ \\
\hline Naprawa, konserwacja i instalowanie maszyn i urządzeń & $-12,0$ & $-20,9$ \\
\hline Pozostała produkcja wyrobów & 1,5 & $-19,2$ \\
\hline Produkcja metali & $-38,6$ & $-18,4$ \\
\hline $\begin{array}{l}\text { Produkcja maszyn i urządzeń, gdzie indziej niesklasyfi- } \\
\text { kowana }\end{array}$ & $-18,4$ & $-13,8$ \\
\hline Produkcja urządzeń elektrycznych & $-10,1$ & $-13,2$ \\
\hline $\begin{array}{l}\text { Produkcja wyrobów z pozostałych mineralnych surowców } \\
\text { niemetalicznych }\end{array}$ & $-13,5$ & $-10,2$ \\
\hline Produkcja wyrobów z gumy i tworzyw sztucznych & $-7,7$ & $-8,7$ \\
\hline Produkcja pozostałego sprzętu transportowego & $-15,7$ & $-7,7$ \\
\hline $\begin{array}{l}\text { Produkcja komputerów, wyrobów elektronicznych i } \\
\text { optycznych }\end{array}$ & $-3,5$ & $-6,4$ \\
\hline $\begin{array}{l}\text { Produkcja artykułów spożywczych, napoje, wyroby } \\
\text { tytoniowe }\end{array}$ & 10,1 & $-5,2$ \\
\hline Produkcja papieru i wyrobów z papieru & 9,1 & $-4,6$ \\
\hline Produkcja chemikaliów i wyrobów chemicznych & 3,3 & 5,4 \\
\hline $\begin{array}{l}\text { Produkcja podstawowych substancji farmaceutycznych } \\
\text { oraz leków i pozostałych wyrobów farmaceutycznych }\end{array}$ & 41,4 & 15,5 \\
\hline Ogółem & $-9,9$ & $-24,1$ \\
\hline \multicolumn{3}{|l|}{ w tym przedsiębiorstwa: } \\
\hline zatrudniające 10-49 pracujących & $-16,0$ & $-31,5$ \\
\hline zatrudniające 50-249 pracujących & $-17,7$ & $-20,0$ \\
\hline zatrudniające 250 i więcej pracujących & $-4,3$ & $-16,8$ \\
\hline
\end{tabular}


112 | Przegląd Prawno-Ekonomiczny

\begin{tabular}{|l|c|c|}
\hline \multirow{2}{*}{ Gałęzie przetwórstwa przemysłowego } & \multicolumn{2}{c|}{$\begin{array}{c}\text { Srednie wskaźniki koniunktury } \\
\text { w latach }\end{array}$} \\
\cline { 2 - 3 } & $2008-2009$ & 2020 \\
\hline \multicolumn{3}{|c|}{ według obszarów działalności } \\
\hline Energia & $-23,6$ & $-32,2$ \\
\hline Dobra inwestycyjne & $-13,2$ & $-30,1$ \\
\hline Trwałe dobra konsumpcyjne & 2,4 & $-28,0$ \\
\hline Dobra pośrednie & $-16,5$ & $-10,8$ \\
\hline Dobra konsumpcyjne & 1,2 & $-9,7$ \\
\hline Nietrwałe dobra konsumpcyjne & 1,2 & $-4,7$ \\
\hline Żywność i napoje & 10,6 & $-2,8$ \\
\hline
\end{tabular}

Źródło: opracowanie własne na podstawie GUS.

Kolejnym sektorem było budownictwo, dla którego nie wydziela się poszczególnych działalności (tabela 3). Jest stosowany podział według skali działania. Ogólnie ten sektor słabiej odczuwał pogorszenie koniunktury gospodarczej na skutek kryzysu gospodarczego w 2020 r. Wyniki jej dotyczące były dosyć podobne w obu kryzysach gospodarczych. Skutki kryzysu gospodarczego bardziej odczuły przedsiębiorstwa najmniejsze, zatrudniające do 9 i od 10 do 49 pracowników. W 2009 r. pogorszenie koniunktury w największych przedsiębiorstwach było większe niż w 2020 r. Epidemia dla wielu dużych zakładów nie oznaczała zatrzymania działalności. Rozpoczęte inwestycje były kontynuowane przy zachowaniu zasad bezpieczeństwa w pracy. Część robót wykonywano na otwartej przestrzeni, a część w budynkach przy zachowaniu odległości.

Tabela 3. Wskaźnik syntetyczny koniunktury gospodarczej w przedsiębiorstwach budowlanych w Polsce

\begin{tabular}{|l|c|c|}
\hline \multirow{2}{*}{ Skala działalności przedsiębiorstwa } & \multicolumn{2}{|c|}{ Średnie wskaźniki koniunktury w latach } \\
\cline { 2 - 3 } & $2008-2009$ & 2020 \\
\hline Ogółem & $-18,8$ & $-24,5$ \\
\hline do 9 pracujących & $-20,7$ & $-28,3$ \\
\hline $10-49$ pracujących & $-20,2$ & $-25,5$ \\
\hline $50-249$ pracujących & $-16,6$ & $-16,0$ \\
\hline 250 i więcej pracujących & $-8,9$ & $-3,3$ \\
\hline
\end{tabular}

Źródło: opracowanie własne na podstawie GUS.

Handel detaliczny został ukazany w podziale według skali działania oraz na podstawowe branże. W 2020 r. na skutek kryzysu gospodarczego najbardziej pogorszyła się koniunktura w przedsiębiorstwach zatrudniających do 9 pracowników, 
a w dalszej kolejności na równi od 50 do 249 pracowników i tych od 10 do 49 pracowników (tabela 4). Najmniejsze spadki koniunktury były w przedsiębiorstwach największych. W 2009 r. sektor handlu detalicznego odnotował nieznaczne jej polepszenie. Jedynie w przedsiębiorstwach zatrudniających do 9 pracowników była gorsza koniunktura gospodarcza. W 2020 r. najbardziej skutki epidemii odczuła branża sprzedaży odzieży i obuwia, w dalszej kolejności samochodów, artykułów AGD, a najmniej żywności. W 2009 r. wszędzie następował wzrost koniunktury, a największy w przypadku sprzedaży artykułów AGD. Występowały więc różnice między oboma kryzysami. Przyczyną pogorszenia się koniunktury w 2020 r. było administracyjne zamknięcie wielu sklepów i niemożność handlu w tradycyjny sposób. Wprawdzie możliwe były zakupy przez Internet, ale część konsumentów ciągle preferuje nabywanie produktów w tradycyjny sposób. Szczególnie w przypadku ubrań i obuwia lepiej jest przymierzyć i sprawdzić w rzeczywistości, czy dany produkt pasuje i odpowiada preferencjom klienta.

Tabela 4. Wskaźnik syntetyczny koniunktury gospodarczej w przedsiębiorstwach zajmujących się handlem detalicznym w Polsce

\begin{tabular}{|l|c|c|}
\hline \multirow{2}{*}{ Skala i rodzaj działalności przedsiębiorstwa } & \multicolumn{2}{|c|}{ Średnie wskaźniki koniunktury w latach } \\
\cline { 2 - 3 } & $2008-2009$ & 2020 \\
\hline Ogółem & 3,8 & $-29,7$ \\
\hline do 9 pracujących & $-9,8$ & $-46,6$ \\
\hline 50-249 pracujących & 16,1 & $-30,5$ \\
\hline 10-49 pracujących & 1,9 & $-28,4$ \\
\hline 250 i więcej pracujących & 24,4 & $-18,3$ \\
\hline Tekstylia, odzież, obuwie & 4,9 & $-65,5$ \\
\hline Pojazdy samochodowe & 5,1 & $-40,0$ \\
\hline Artykuły gospodarstwa domowego ogółem & 23,3 & $-34,7$ \\
\hline Żywność & 3,0 & $-7,6$ \\
\hline
\end{tabular}

Źródło: opracowanie własne na podstawie GUS.

W sektorze usług występowało duże zróżnicowanie w koniunkturze gospodarczej, w zależności od branży (tabela 5). W $2020 \mathrm{r}$. największe jej pogorszenie nastąpiło w działalności związanej z zakwaterowaniem i usługami gastronomicznymi, w dalszej kolejności w edukacji, branży kulturalnej, rozrywkowej i rekreacyjnej. W działalności transportowej spadki koniunktury były największe w przypadku transportu lądowego. Gorsze wyniki osiagnęła ona także w przypadku usług profesjonalnych w zakresie architektury, inżynierii, badań i analiz technicznych, doradztwa w zarządzaniu, porad prawniczych. Drastyczny spadek koniunktury nastąpił w branży zajmującej się organizacją turystyki, a także 
produkcją filmów, programów telewizyjnych. Wszystkie te działalności zostały zawieszone lub ograniczone w wyniku zakazów administracyjnych i zaleceń pozostania w domu. Były jednak branże, które bardzo dobrze funkcjonowały w czasie epidemii, jak zajmujące się ubezpieczeniami, usługami finansowymi, nadawaniem programów telewizyjnych (stacje telewizyjne), usługami w zakresie informatyki, informacji, telekomunikacji, wynajmu i dzierżawy, badań naukowych. W tych branżach możliwe było świadczenie usług w sposób zdalny. Epidemia i ograniczenia w wielu przypadkach przyczyniły się do przestawienia przedsiębiorstw i ich klientów na zdalny sposób komunikowania się i wykonywania zleconych zadań. W przypadku stacji telewizyjnych przyczyną lepszej koniunktury było oczywiście pozostanie wielu ludzi w swoich domach i chęć zapełnienia wolnego czasu właśnie poprzez oglądanie telewizji.

Tabela 5. Wskaźnik syntetyczny koniunktury gospodarczej w przedsiębiorstwach zajmujących się handlem detalicznym w Polsce

\begin{tabular}{|l|l|c|c|}
\hline \multirow{2}{*}{ Kod } & \multicolumn{1}{|c|}{ Działalności } & \multicolumn{2}{|c|}{$\begin{array}{r}\text { Średnie wskaźniki koniunk- } \\
\text { tury w latach }\end{array}$} \\
\cline { 3 - 4 } & & $2008-2009$ & 2020 \\
\hline I & $\begin{array}{l}\text { Działalność związana z zakwaterowa- } \\
\text { niem i usługami gastronomicznymi }\end{array}$ & $-1,5$ & $-63,9$ \\
\hline S & Pozostała działalność usługowa & $-7,8$ & $-61,7$ \\
\hline P & Edukacja & $-2,5$ & $-43,2$ \\
\hline R & $\begin{array}{l}\text { Działalność związana z kulturą, rozrywką } \\
\text { i rekreacją }\end{array}$ & 11,1 & $-34,8$ \\
\hline H & Transport i gospodarka magazynowa & $-17,5$ & $-24,8$ \\
\hline 49 & Transport lądowy oraz transport rurociągowy & $-24,2$ & $-33,8$ \\
\hline Q & Opieka zdrowotna i pomoc społeczna & 19,7 & $-23,0$ \\
\hline $\mathbf{M}$ & $\begin{array}{l}\text { Działalność profesjonalna, naukowa } \\
\text { i techniczna }\end{array}$ & 4,4 & $-11,9$ \\
\hline 69 & $\begin{array}{l}\text { Działalność prawnicza, rachunkowo-księgowa i do- } \\
\text { radztwo podatkowe }\end{array}$ & 18,3 & $-4,6$ \\
\hline 70 & $\begin{array}{l}\text { Działalność firm centralnych (head offices); doradz- } \\
\text { two związane z zarządzaniem }\end{array}$ & $-8,0$ & $-8,8$ \\
\hline 71 & $\begin{array}{l}\text { Działalność w zakresie architektury i inżynierii, } \\
\text { badania i analizy techniczne }\end{array}$ & 0,5 & $-15,4$ \\
\hline 72 & Badania naukowe i prace rozwojowe & 0,4 & 39,5 \\
\hline 73 & Reklama, badanie rynku i opinii publicznej & $-35,4$ \\
\hline
\end{tabular}




\begin{tabular}{|c|c|c|c|}
\hline 74 & $\begin{array}{l}\text { Pozostała działalność profesjonalna, naukowa } \\
\text { i techniczna }\end{array}$ & $-0,3$ & $-24,4$ \\
\hline $\mathrm{N}$ & $\begin{array}{l}\text { Działalność w zakresie usług administrowa- } \\
\text { nia i działalność wspierająca }\end{array}$ & $-3,1$ & $-10,6$ \\
\hline 77 & Wynajem i dzierżawa & 1,4 & 27,2 \\
\hline 78 & Działalność związana z zatrudnieniem & $-19,5$ & $-6,2$ \\
\hline 79 & $\begin{array}{l}\text { Działalność organizatorów turystki, pośredników } \\
\text { i agentów turystycznych oraz pozostała działalność } \\
\text { usługowa w zakresie rezerwacji i działalności z nią } \\
\text { związane }\end{array}$ & $-11,6$ & $-70,7$ \\
\hline 80 & Działalność detektywistyczna i ochroniarska & $-2,4$ & $-11,1$ \\
\hline 81 & $\begin{array}{l}\text { Działalność usługowa związana z utrzymaniem po- } \\
\text { rządku w budynkach i zagospodarowaniem terenów } \\
\text { zieleni }\end{array}$ & 4,0 & $-23,3$ \\
\hline $\mathrm{L}$ & $\begin{array}{l}\text { Działalność związana z obsługą rynku } \\
\text { nieruchomości }\end{array}$ & 12,2 & 7,4 \\
\hline $\mathrm{J}$ & Informacja i komunikacja & 22,1 & 20,5 \\
\hline 58 & Działalność wydawnicza & 12,4 & 2,9 \\
\hline 59 & $\begin{array}{l}\text { Działalność związana z produkcją filmów, nagrań } \\
\text { wideo, programów telewizyjnych, nagrań dźwięko- } \\
\text { wych i muzycznych }\end{array}$ & $-17,9$ & $-42,6$ \\
\hline 60 & $\begin{array}{l}\text { Nadawanie programów ogólnodostępnych i abona- } \\
\text { mentowych }\end{array}$ & 25,2 & 47,5 \\
\hline 61 & Telekomunikacja & 40,8 & 25,3 \\
\hline 62 & $\begin{array}{l}\text { Działalność związana z oprogramowaniem i do- } \\
\text { radztwem w zakresie informatyki oraz działalność } \\
\text { powiązana }\end{array}$ & 14,4 & 21,0 \\
\hline 63 & Działalność usługowa w zakresie informacji & 21,9 & 22,6 \\
\hline $\mathrm{K}$ & Działalność finansowa i ubezpieczeniowa & 31,3 & 32,2 \\
\hline 64 & $\begin{array}{l}\text { Finansowa działalność usługowa, z wyłączeniem } \\
\text { ubezpieczeń i funduszów emerytalnych }\end{array}$ & 32,2 & 22,1 \\
\hline 65 & $\begin{array}{l}\text { Ubezpieczenia, reasekuracja oraz fundusze emery- } \\
\text { talne, } \mathrm{z} \text { wyłączeniem obowiązkowego ubezpieczenia } \\
\text { społeczego }\end{array}$ & 37,2 & 49,0 \\
\hline
\end{tabular}

Źródło: opracowanie własne na podstawie GUS.

W latach 2008-2009 skala spadku koniunktury była dużo mniejsza niż w 2020 r. Ranking branż, które najbardziej odczuły skutki kryzysu, był inny. Najgorszą sytuację odnotowano w transporcie, usługach związanych z zatrudnieniem, produkcji filmów i programów telewizyjnych. Wykaz branż o najlepszej koniunkturze gospodarczej był z kolei podobny do 2020 r. Wykaz objął również 
branże umożliwiające zdalne wykonywanie usług, bez konieczności spotkania się osobistego, czyli dotyczące szeroko rozumianej informacji i komunikacji oraz działalności finansowej i ubezpieczeniowej. Korzystna była też sytuacja w przypadku usług opieki zdrowotnej, prawniczej, rachunkowej i podatkowej, a także związanych z kulturą. Uwidoczniły się różnice w tych ostatnich grupach działalności. Podstawową przyczyną był administracyjny zakaz działalności w 2020 r., co skutkowało brakiem możliwości zarabiania przez przedsiębiorstwa świadczące usługi na miejscu.

W marcu stwierdzono 2311 zachorowań na COVID-19, a w kolejnych miesiącach podobną liczbę po ok. 10 tys. przypadków. Odpowiednio w kwietniu zachorowały 10564 osoby, w maju - 10911 i czerwcu - 10 607. Zachorowania rozkładały się jednak różnie w poszczególnych województwach Polski. Do określenia stopnia koncentracji liczby zachorowań na COVID-19 w województwach w relacji z innymi województwami zastosowano współczynnik Giniego. Dane dotyczyły czterech miesięcy 2020 r. - od marca do czerwca - liczba zaś obserwacji wynosiła 16 . Współczynnik Giniego był obliczany z próby oraz był estymowany. Wyniki zbliżone do 1 oznaczają dużą koncentrację, zbliżone zaś do 0 jej brak. Systematycznie wzrastał poziom koncentracji zachorowań w kilku województwach, gdyż współczynnik Giniego z próby wynosił odpowiednio dla marca 0,43 (estymowany 0,45 ), dla kwietnia 0,47 (estymowany 0,50 ), dla maja aż $0,72(0,77)$ i dla czerwca $0,64(0,68)$. Koncentrację liczby zachorowań na COVID-19 i zróżnicowanie występujące w województwach przedstawiono za pomocą krzywych koncentracji Lorenza (rysunek 2). W marcu najwięcej zachorowań było w województwach: mazowieckim, dolnośląskim i śląskim, w kwietniu zaś liczba przypadków była podobna w śląskim i mazowieckim, a dalej były województwa wielkopolskie i dolnośląskie. W maju osiągnięto wysoką koncentrację zachorowań na skutek stwierdzenia dużych ognisk choroby w kopalniach w województwie śląskim. Wtedy ok. 55\% wszystkich przypadków zachorowań było w tym województwie. W czerwcu sytuacja na Śląsku poprawiła się, ale nadal było tam prawie $42 \%$ zachorowań w Polsce. 
Rysunek 2. Krzywe koncentracji Lorenza dla liczby zachorowań na COVID-19 w województwach Polski

Liczba zachorowań w marcu 2020 r.

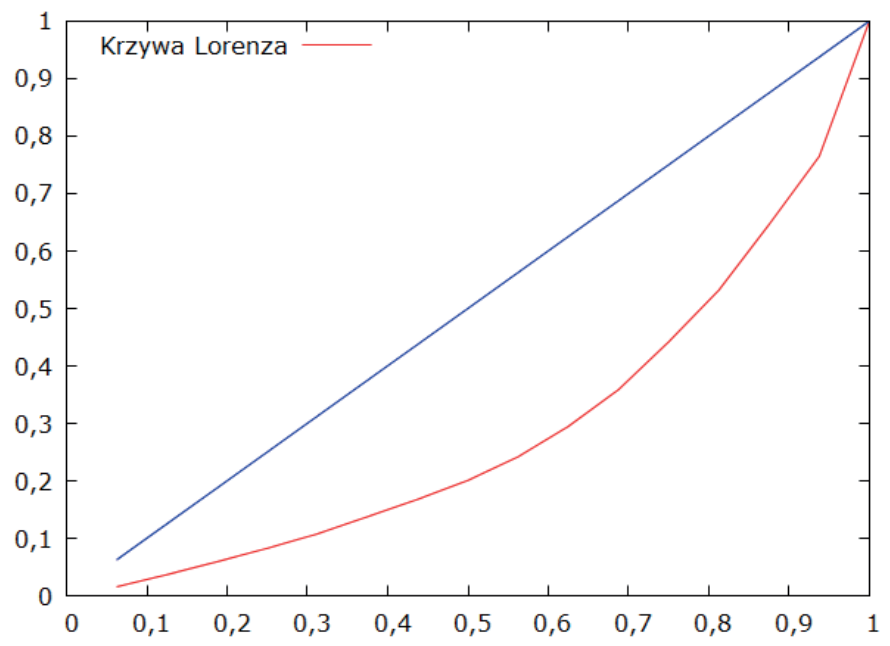

Liczba zachrowań w kwietniu 2020 r.

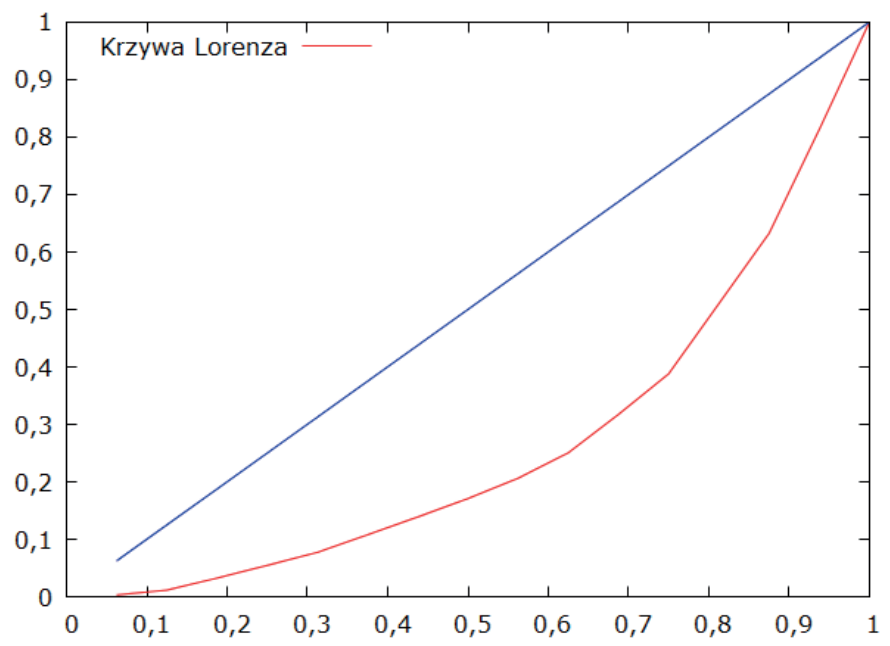


Liczba zachrowań w maju 2020 r.

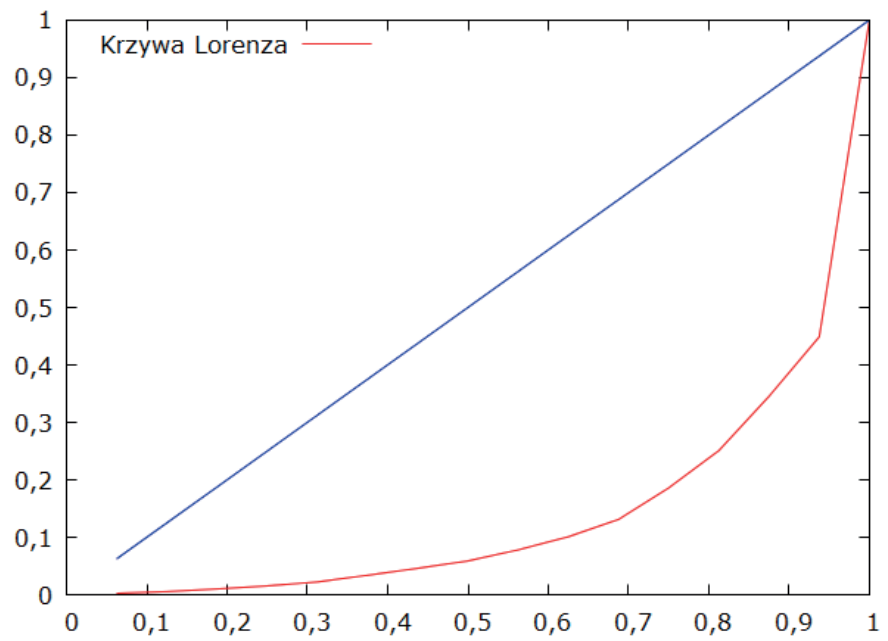

Liczba zachrowań w czerwcu 2020 r.

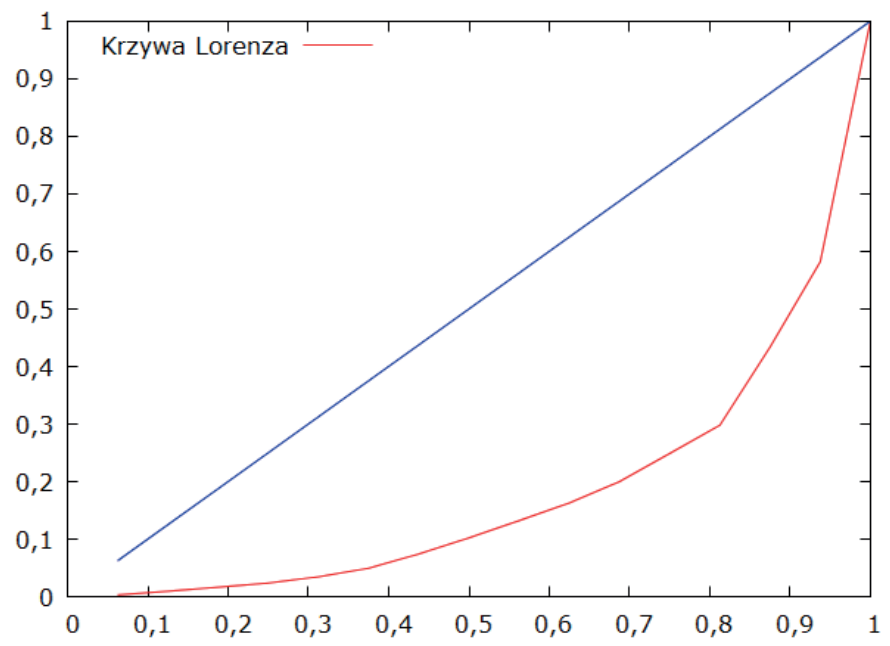

Źródło: opracowanie własne.

W celu stwierdzenia związku między liczbą zachorowań na COVID-19 w poszczególnych województwach a koniunkturą gospodarczą zostały obliczone współczynniki korelacji liniowej Pearsona (tabela 6). Wprawdzie województwa nie różniły się między sobą ograniczeniami administracyjnymi dotyczącymi aktywności osób fizycznych i przedsiębiorstw, ale liczba zachorowań była dosyć 
zróżnicowana, tzn. były województwa z bardzo małą liczbą zachorowań i takie, które miały w tym zakresie bardzo wysokie statystyki. Według autora mógł istnieć związek między liczbą zachorowań i większymi obawami a koniunkturą gospodarczą, tzn. w regionach o wysokich statystykach zakażeń ludzie mogli $\mathrm{z}$ większą obawą podchodzić do prowadzenia działalności i aktywności indywidualnej, wyjść na zakupy itp. Sytuacja taka mogła być uzasadniona z uwagi na nowe, niespotykane wcześniej okoliczności i dużą obawę co do konsekwencji zachorowania. Powikłania powodowały nawet śmierć. Ciekawe było też określenie, czy prawidłowości były zależne od działu gospodarki. Jako wartość graniczną poziomu istotności przyjęto $\mathrm{p}=0,10$. Zestawienie wykonano dla poszczególnych miesięcy $2020 \mathrm{r}$. od kwietnia do czerwca oraz dla całego tego okresu. Istotne wyniki zostały oznaczone pogrubionym tekstem w tabeli. Współczynniki korelacji zostały policzone dla województwa w pojedynczych miesiącach, jak i w całym okresie od kwietnia do czerwca 2020 r. W pracy starano się sprawdzić korelację, która nie wskazuje, że dany czynnik wpływa na inny, tylko że istnieje między nimi silny lub słaby związek. Stwierdzono jedynie słaby związek w przypadku koniunktury w transporcie i magazynowaniu dla czerwca 2020 r. i dla całego okresu od kwietnia do czerwca 2020 r. Większej liczbie zachorowań na COVID-19 w danym województwie odpowiadała na ogół lepsza koniunktura w działalności transportowej i magazynowej. Trudniejsza sytuacja epidemiologiczna w danym województwie wiązała się np. z koniecznością dostarczenia towarów i przesyłem z wykorzystaniem zewnętrznych przewoźników. W przypadku pozostałych działalności nie stwierdzono istotnych związków. 


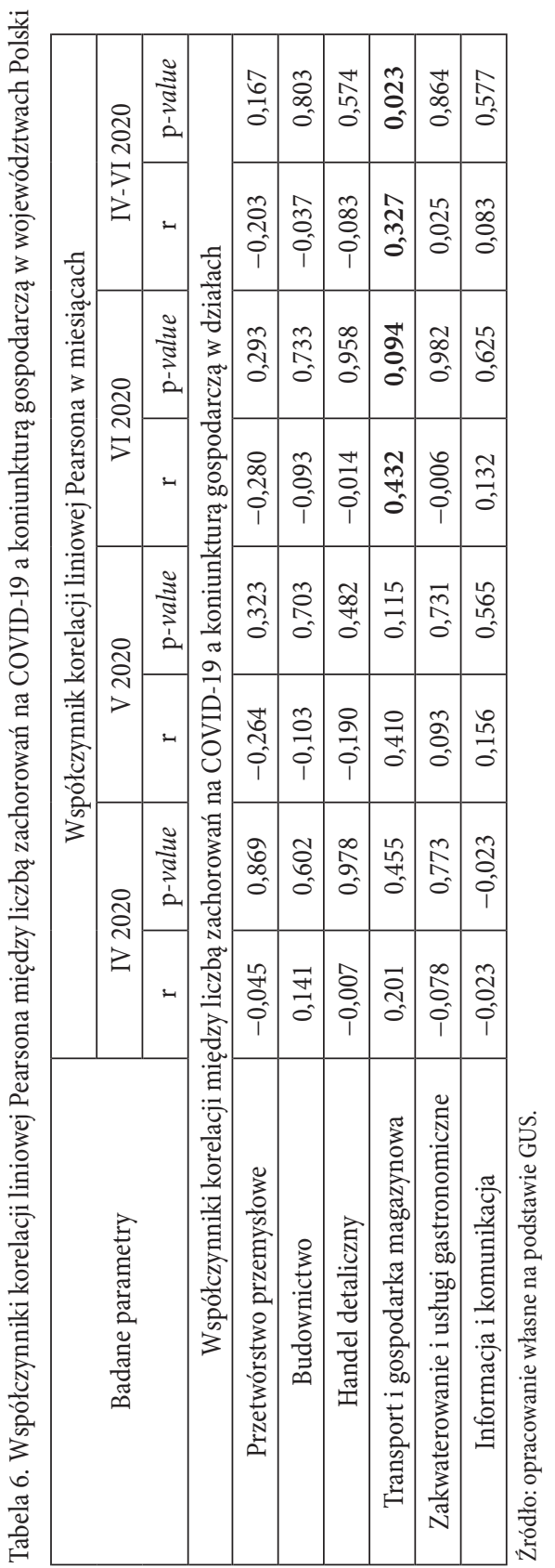


Na koniunkturę gospodarczą ma wpływ wiele czynników w bliższym i dalszym otoczeniu biznesu oraz wewnątrz i na zewnątrz systemu gospodarczego (Adamowicz i Walczyk, 2017). Kryzysy finansowe i gospodarcze trwale wpływają na zmiany w polityce makroekonomicznej w europejskim obszarze gospodarczym (Gierańczyk, 2014; Rachwał, 2014). Ryzyko prowadzenia działalności można oszacować, jednak są problemy w określeniu niepewności. Wzrost niepewności przekłada się na nastroje uczestników rynku i wyniki działalności gospodarczej. W rezultacie następują zaburzenia wzorców zachowań (Akerlof i Kranton, 2000; Haselton i Nettle, 2006; Hertwig i Erev, 2009; Johnson i Fowler, 2011). Kryzys gospodarczy z lat 2008-2009 ukazał pewne zależności. Pogorszenie koniunktury występowało w krajach i regionach o dużej koncentracji przemysłu. Można było również wyróżnić konkretne branże (Gajdzik, 2010; Rachwał, 2011; Šerý, 2011). Dodatkowo zmiany koniunktury w przemyśle i transporcie wyprzedzały i sygnalizowały zmiany w dynamice wahań PKB. W przypadku budownictwa nie było takiej zależności. Wzrost koniunktury w handlu z kolei sygnalizował nadchodzące ożywienie gospodarcze, spadki zaś następowały z opóźnieniem. W poszczególnych sektorach różne są również czasy trwania poszczególnych faz spadkowych i wzrostowych, tj. najdłuższe $\mathrm{w}$ transporcie, a najkrótsze $\mathrm{w}$ handlu. Wskaźnik koniunktury gospodarczej w przypadku handlu wykazuje najmniejszą zmienność, największą zaś w transporcie (Adamowicz i Walczyk, 2013a, 2013b). W czasie kryzysu następuje załamanie się działalności przemysłowej i związanej z dobrami kapitałowymi oraz wzrost wydatków konsumenckich i sprzedaży detalicznej (Salerno, 2012). Zaobserwowane w artykule prawidłowości w zakresie koniunktury gospodarczej w Polsce w czasie kryzysu gospodarczego są w większości zgodne z wynikami badań innych autorów.

\section{Podsumowanie}

COVID-19 przyczynił się do wywołania kryzysu gospodarczego w wielu krajach świata. W Polsce widoczny był bardzo duży spadek koniunktury gospodarczej od kwietnia do czerwca 2020 r. Skutki kryzysu gospodarczego dotknęły wszystkie sektory, jednak w różnym stopniu. W 2020 r. największe pogorszenie się koniunktury gospodarczej wystąpiło zdecydowanie w sektorze usług, dalej w handlu detalicznym, przemyśle, najmniejsze zaś w budownictwie. W latach 2008-2009 kryzys gospodarczy najbardziej wpłynął na przetwórstwo przemy- 
słowe, następnie na budownictwo, najmniej zaś na handel detaliczny i usługi. Występowały jednak różnice w poszczególnych branżach i działalnościach.

W przetwórstwie przemysłowym najgorsza sytuacja była w obszarze związanym z produkcją energii, dóbr inwestycyjnych i trwałych dóbr konsumpcyjnych, najlepsza zaś w branży żywności i napoi oraz nietrwałych dóbr konsumpcyjnych. W trakcie epidemii ludzie musieli zaspokajać swoje podstawowe potrzeby fizjologiczne, zrezygnowali zaś z dóbr wyższego rzędu i inwestycji, po części na skutek zawieszenia wielu działalności i zakazu wychodzenia z domu. W latach 2008-2009 skala pogorszenia koniunktury była mniejsza, występowały też różnice w działalnościach najbardziej odczuwających skutki kryzysu. Główną przyczyną były administracyjne ograniczenia działalności, które wykluczały popyt na dane produkty. $Z$ reguły większe przedsiębiorstwa mniej odczuwały skutki kryzysu gospodarczego. Podobne zależności zaobserwowano w budownictwie - duże firmy radziły sobie lepiej. Dodatkowo sektor budownictwa był najmniej dotknięty kryzysem gospodarczym. Podobnie sytuacja wyglądała w latach 2008-2009. Identycznie było też w handlu detalicznym. Największe problemy w tym sektorze miały najmniejsze przedsiębiorstwa, a także zajmujące się sprzedażą odzieży i obuwia, samochodów i sprzętu AGD. W przypadku tego sektora główną przyczyną gorszej koniunktury było administracyjne zamknięcie sklepów. W obszarze usług zależności były podobne w czasie obu kryzysów. Na znaczeniu zyskiwały działalności, które mogły być wykonywane zdalnie, bez konieczności bezpośredniego kontaktu, jak z branży informatycznej i finansowej. Wymagały one pracy zdalnej. Były też działalności, które tak jak wcześniej traciły na skutek zakazu prowadzenia działalności.

Na koniunkturę gospodarczą w czasie epidemii miały wpływ zakaz administracyjny prowadzenia działalności oraz możliwość wykonywania pracy zdalnej. Te działalności, które były wykonywane zdalnie, zyskiwały lub traciły mniej. W przypadku braku takiej możliwości i zamknięciu zakładu nie było szansy na uzyskiwanie zadawalających przychodów. Kryzysy gospodarcze z 2020 i lat 2008-2009 różniły się znacząco pod względem skali, mniej zaś pod względem oddziaływania na konkretne działalności. Potwierdzona została postawiona w pracy hipoteza badawcza.

Przy uwzględnieniu liczby zachorowań w poszczególnych województwach nie stwierdzono istotnego ich związku $\mathrm{z}$ koniunkturą $\mathrm{w}$ podstawowych sektorach i działach gospodarki. Stwierdzono jedynie słabą dodatnią korelację z transportem i magazynowanie w czerwcu $2020 \mathrm{r}$. oraz w całym okresie od kwietnia do czerwca 2020 r. Większa liczba przypadków zachorowań w danym 
województwie wiązała się z lepszą koniunkturą i zapotrzebowaniem na usługi przewozowe, dostawy towarów bezpośrednio do domów.

\section{Bibliografia}

\section{Akty prawne}

Rozporządzenie Ministra Zdrowia z dnia 13 marca 2020 r. w sprawie ogłoszenia na obszarze Rzeczypospolitej Polskiej stanu zagrożenia epidemicznego, Dz.U. 2020, poz. 433.

Rozporządzenie Ministra Zdrowia z dnia 20 marca 2020 r. w sprawie ogłoszenia na obszarze Rzeczypospolitej Polskiej stanu epidemii, Dz.U. 2020, poz. 491.

\section{Literatura}

Adamowicz, E., Walczyk, K. (2013a). Jakościowy cykl koniunkturalny w Polsce. Sektorowe zmiany aktywności gospodarczej. Przegląd Zachodniopomorski, 3(1), 7-20.

Adamowicz, E., Walczyk, K. (2013b). Stylised Facts about Cyclical Fluctuations of Business Survey Data. Prace i Materiały Instytutu Rozwoju Gospodarczego SGH, 93(Expectations and Forecasting), 123-142.

Adamowicz, E., Walczyk, K. (2017). Zaburzenia cykliczności aktywności gospodarczej w Polsce w świetle wyników badania koniunktury gospodarczej IRG SGH. Prace i Materiały Instytutu Rozwoju Gospodarczego/Szkoła Główna Handlowa, 101(Niepewność a aktywność gospodarcza), 5-25.

Akerlof, G. A., Kranton, R. E. (2000). Economics and identity. The quarterly journal of economics, 115(3), 715-753.

Chen, N., Zhou, M., Dong, X., Qu, J., Gong, F., Han, Y., Yu T. (2020). Epidemiological and clinical characteristics of 99 cases of 2019 novel coronavirus pneumonia in Wuhan, China: a descriptive study. The Lancet, 395(10223), 507-513.

Gajdzik, B. (2010). Reakcja przedsiębiorstw hutniczych na światowy kryzys gospodarczy. Prace Naukowe/Akademia Ekonomiczna w Katowicach, 1, 74-86.

Gierańczyk, W. (2014). Economic situation in the manufacturing sector as an example of modern research in industrial geography in Poland. Prace Komisji Geografii Przemysłu Polskiego Towarzystwa Geograficznego, 25, 38-55.

Haselton, M. G., Nettle, D. (2006). The paranoid optimist: an integrative evolutionary model of cognitive biases. Personality and Social Psychology Review, 10, 47-66.

Hertwig, R., Erev, I. (2009). The description-experience gap in risky choice. Trends in cognitive sciences, 13(12), 517-523. 
Huang, C., Wang, Y., Li, X., Ren, L., Zhao, J., Hu, Y., Cheng, Z. (2020). Clinical features of patients infected with 2019 novel coronavirus in Wuhan, China. The Lancet, 395(10223), 497-506.

Jarynowski, A., Wójta-Kempa, M., Płatek, D., Czopek, K. (2020). Attempt to understand public health relevant social dimensions of COVID-19 outbreak in Poland. Pobrano z: https://papers.ssrn.com/sol3/papers.cfm?abstract_id=3570609, 1-51 (10.07.2020).

Jayadev, C., Shetty, R. (2020). Commentary: What happens after the lockdown? Indian Journal of Ophthalmology, 68(5), 730-731.

Johnson, D. D., Fowler, J. H. (2011). The evolution of overconfidence. Nature, 477(7364), 317-320.

Lu, H., Stratton, C. W., \& Tang, Y. W. (2020a). Outbreak of pneumonia of unknown etiology in Wuhan, China: The mystery and the miracle. Journal of Medical Virology, 92(4), 401-402.

Lu, H., Stratton, C. W., \& Tang, Y. W. (2020b). The Wuhan SARS-CoV-2 - What's next for China. Journal of Medical Virology, 92(6), 546-547.

Poberezhets, O. V. (2015). Multi-criteria system of evaluating the economic situation sectors enterprises. Экономика: реалии времени, 4(20), 52-58.

Rachwał, T. (2011). The impact of crisis on changes in industrial production in Poland. Studies of the Industrial Geography Commission of the Polish Geographical Society, 17, 99-113.

Rachwał, T. (2014). Changes in the spatial structure of the Polish industry under economic crisis conditions. Studies of the Industrial Geography Commission of the Polish Geographical Society, 27, 148-163.

Salerno, J. T. (2012). A reformulation of Austrian business cycle theory in light of the financial crisis. Quarterly Journal of Austrian Economics, 15(1), 3-44.

Serwis Rzeczypospolitej Polskiej. (2020). Mapa zakażeń koronawirusem w Polsce. Pobrano z: https://www.gov.pl/web/koronawirus/wykaz-zarazen-koronawirusem-sars-cov-2 (10.07.2020)

Šerý, O. (2011). The impact of economic crisis on regions dominated by motor vehicles industry (the case of Vysočina Region). Prace Komisji Geografii Przemystu Polskiego Towarzystwa Geograficznego, 17, 155-163.

Shetty, R., Ghosh, A., Honavar, S. G., Khamar, P., Sethu, S. (2020). Therapeutic opportunities to manage COVID-19/SARS-CoV-2 infection: Present and future. Indian Journal of Ophthalmology, 68(5), 693.

World Health Organization. (2020a). WHO Director-General's opening remarks at the media briefing on COVID-19 - 11 March 2020. Pobrano z: https://www.who.int/ 
$\mathrm{dg} /$ speeches/detail/who-director-general-s-opening-remarks-at-the-media-briefing-on-covid-19---11-march-2020 (10.07.2020).

World Health Organization. (2020b). WHO Coronavirus Disease (COVID-19) Dashboard. Pobrano z: https://covid19.who.int/ (10.07.2020).

\section{Streszczenie}

Celem głównym pracy było rozpoznanie sytuacji i przedstawienie zmian w koniunkturze gospodarczej Polski w wyniku epidemii COVID-19. Źródła materiałów stanowiła literatura przedmiotu, dane GUS. W pracy wykorzystano metodę porównawczą, posługiwano się wskaźnikami koniunktury, obliczono współczynnik koncentracji Giniego dla liczby zachorowań oraz przedstawiono stopień koncentracji za pomocą krzywej Lorenza. Zastosowano również współczynniki korelacji liniowej Pearsona. Do prezentacji wyników badań wykorzystano metodę opisową, tabelaryczna i graficzną. Stwierdzono pogorszenie się koniunktury gospodarczej we wszystkich sektorach gospodarki, największe w usługach i przemyśle, najmniejsze zaś w budownictwie. Występowały też różnice w działalnościach przypisanych do poszczególnych sektorów. Z reguły większe przedsiębiorstwa mniej odczuwały skutki kryzysu gospodarczego. Skala pogorszenia się koniunktury w 2020 r. była większa niż w latach 2008-2009. W czasie epidemii miały na nią wpływ zakaz administracyjny prowadzenia działalności oraz możliwość wykonywania pracy zdalnej. Te działalności, które były wykonywane zdalnie, zyskiwały lub traciły mniej. W przypadku braku takiej możliwości i zamknięciu zakładu nie było szansy na uzyskiwanie zadawalających przychodów. Większa liczba przypadków zachorowań w danym województwie wiązała się z lepszą koniunkturą i zapotrzebowaniem na usługi przewozowe, dostawy towarów bezpośrednio do domów.

SŁOWA KLUCZOWE: COVID-19, koniunktura gospodarcza, sektory gospodarki, kryzys gospodarczy.

\section{Summary}

The main aim of the work was to identify the situation and present changes in the economic climate in Poland as a result of the COVID-19 epidemic. The sources of materials were the literature on the subjectas well es data from the Central Statistical Office. The work uses a comparative method, the indicators of the economic situation were used, the Gini concentration coefficient for the number of cases was calculated and the degree of concentration was presented using the Lorenz curve. Pearson's linear correlation coefficients were also used. The descriptive, tabular and graphic methods were used to present the research results. The deterioration of the economic situation was found in all sectors of the economy, the greatest in services and industry, and the smallest in construction. There were also differences in the activities assigned to particular sectors. As a rule, larger enterprises were less affected by the economic crisis. The scale of the economic downturn in 2020 was greater than in 2008-2009. The economic situation 
during the epidemic was influenced by the administrative ban on conducting business activity and the possibility of remote work. Activities that were performed remotely gained or lost less. In the absence of such a possibility and the closure of the plant, there was no chance of obtaining satisfactory revenues. The greater number of cases in a given voivodeship was associated with better economic conditions and the demand for transport services, delivery of goods directly to homes.

KeYwords: COVID-19, economic situation, sectors of the economy, economic crisis.

Nota o autorze

Tomasz Rokicki - dr hab. inż., Szkoła Głowna Gospodarstwa Wiejskiego w Warszawie, Wydział Ekonomiczny, Katedra Logistyki; główne obszary działalności naukowej: dziedzina nauk społecznych, dyscyplina ekonomia i finanse; e-mail: tomasz_rokicki@sggw.pl; ORCID: 0000-0003-3356-2643. 